\title{
The Effects of Determinants of Government Expenditure on Education and Health: Evidence From SADC Economies
}

\author{
Horisani Mhlari and Teboho Jeremiah Mosikari
}

\section{School of Economic Sciences, Department of Economics, North West University, South Africa}

\begin{abstract}
Health and education expenditure play a major role in determining the well-being and development of the people. However, SADC economies have poor health and education indicators, despite high expenditure by governments. The purpose of this study is to assess the determinants of government expenditure on health and education in SADC countries. This study used the annual data covering the period 1997 to $2017 . \mathrm{FMOLS}^{1}$ and DOLS ${ }^{2}$ are applied to estimate the parameters of each variable understudy. The techniques were developed to estimate and test hypothesis about cointegrating vector to panel data. Overall the results revealed that gross domestic product, population growth and corruption are crucial determinants of health and education expenditure in SADC countries. Therefore, governments in SADC can implement policy that are pro economic growth, and measures that discourages corruption. This can be achieved by allocating high budget on education expenditure, and implementing independent corruption agencies.
\end{abstract}

Keywords: Government Expenditure, Government Expenditure on Education, Government Expenditure on Health, Corruption, Economic Growth, Population, Panel data.

\section{INTRODUCTION}

A healthy population is an essential catalyst for economic and social development (SADC $\left.{ }^{3}, 2019 a\right)$. Health care is the major element of human capital investment, thus rising national expenditure on health will increase life quality, labour productivity, and general being of the people (Culyer and Newhouse, 2000). Communicable diseases are a serious concern for social and human development in the region (WHO, 2019). SADC accounts for $33 \%$ of all people living with HIV and AIDS in the world; eight SADC member countries are among those economies with the highest percentages of tuberculosis; and $75 \%$ of the SADC population is in danger of contracting malaria (SADC,2019b). In 1999, SADC signed health protocol aimed among other, to create a joint strategy to address the health problems for children, women and another defenceless populace. SADC economies spend an average of $10 \%$ of their national budget on health, which is the second highest in the budget following education (SADC, 1999). However, health and social indicators are the worst in the region (WHO, 2019). According to the SADC (2018) majority of the people residing in the region suffer mainly from preventable illness which could be prevented at little cost. Thus, it is important to understand the impacts of the determinants of government expenditure on health in SADC.

*Address correspondence to this author at the School of Economic Sciences, Department of Economics, North West University, South Africa;

E-mail: tebohomosikari@gmail.com

JEL classification: H51, H52, D57, 04, P23, C23.

${ }^{1}$ Fully modified Ordinary Least Squares

${ }^{2}$ Dynamic Ordinary Least Squares

${ }^{3}$ Southern African Development Community (SADC)
Furthermore, SADC member states spend large amount of money on education to affect growth and development in their economies. According to SADC (2017), SADC member countries spent an average of $23 \%$ on education expenditure, which makes it the largest component of government expenditure. There are a few policies in place to address the education problems in SADC economies. In 1997 SADC countries signed education protocol which address the quality and cohesion of education within the members states. The protocol acknowledged the need to develop the human resource capacity of the community, and the purpose of the Protocol is to overcome the difficulties faced by individual economy in their attempts to build successful education systems. However, there are still challenges that prevent total access of education in the region.

Population of SADC economies is youthful, where $76.4 \%$ of the population is below the age of 35 (SADC, 2011). Literature shows that in developed economies as population grow, the aging will increase political pressure to move the composition of social expenditure in favour of the elderly but sacrificing other government expenditure such as education (Dormont, Grignon and Huber, 2006. Corruption is growing at a geometric rate in the SADC region, most government in the region blame past racial segregation for the presence of corruption in their respective economies. According to Gumede (2010) corruption comes in two forms: Firstly, what he calls big time corruption, when public official changes the rules to propel patronage to relatives. Secondly, is what he called pretty corruption, when government workers intentionally neglect their responsibilities to deliver public service. SADC has enjoyed positive economic growth recently. According to the African Development Bank Group (2019) SADC economies recorded $2.1 \%$ growth in 2018 and rose to 
$2.4 \%$ in 2019 . Service sector has been widely cited as the main contributor of increase in gross domestic product in the region. However, growth rate is below macroeconomic convergence rate of $7 \%$ per year.

This study is motivated by the following factors: firstly, there is no existing empirical literature on government expenditure on health and education in SADC countries. Except for the work of Mussagy and Babatunde (2015) which whoever focused on education and economic growth in Mozambique exclusively than considering SADC economies as an economic unit. Lastly, the literature survey shows that no attention was given to explore the econometric method of panel Fully Modified Ordinary Least Squared (FMOLS) and Dynamic Ordinary Least Square (DOLS). The interest of such use of techniques is that in a case of pre-existence of cointegration among the system it is best to use this parameter estimates since they do not require post-estimation diagnostics. Therefore, this gaps warrants an investigation in SADC economies. Therefore, the purpose of this study is to identify the determinants of government expenditure on health and education in SADC. In which it can be established how this factors affect government expenditure on health and education in SADC countries. This will be done by explaining the determinants and their behavior on government expenditure on Education and Health. Positively, this study will assist policy makers to design strong socioeconomic policies designated to SADC economies. In addition, this study will serve as a recent source of information for researchers as the findings will inform debates on the subject. This study is structured as follows: Section 2 is the literature survey studies; Section 3 presents research methodology; Section 4 presents empirical results. Section 5 concludes the study.

\section{LITERATURE SURVEY}

This study follows two theoretical studies, the theory of pure public expenditure and Wagner's law. The theory of public expenditure was brought to existence by Paul Samuelsson in 1954, in his study the pure theory of public expenditure. The study divides the national budget into two sections; (i) algebraic taxes and transfers, known as income redistribution which can be changed until the society is moved to optimal condition; (ii) the provision of the collective goods. Samuelsson (1954) defines collective goods as goods that are consumed by everyone in common. Therefore, the consumption of these goods and services by one person, does not reduce the consumption of the same goods to the next person. Samuelson (1954) further extended the theory specifically to cover for government expenditure on education. $\mathrm{He}$ acknowledges the fact that education is private consumption service which can be divided equal between individuals. He added, that education is the only instrument in which the have-not can build up their capital. Furthermore, the theory claimed that government expenditure on education especial on high education serve the interest of government better, because it makes the youth or student to be more compliant citizens.

Adolph Wagner (1835 - 1917), a German economist, in 1880 theorised a well-known association between the growth of the economy and relative growth in public expenditure activities. The law state that as per capita gross national product raise, public expenditure will increase. That is, as income rises, the demand for goods and services provided by the state increases, mainly because of the technological requirements of industrialization and urbanization that supplement the income growth. Furthermore, Wagner thinks of government expenditure as the endogenous factor that is initiated by economic growth rather than exogenous factor. Wagner provides two explanations for the growth of the public sector expenditure as income escalates. Firstly, when these services provided are basic needs, such as administration, education, protection, law and order, health, redistribution of income, and capital expenditure that complement the process of industrialization. Secondly, a significant expansion of cultural and welfare expenditures, with respect to education and income redistribution, takes place as income increases.

Literature reveals that there is a number of determinants for health and education expenditure such as corruption, federalism, economic growth, population and so forth (Kotera and Okada, 2017; Loto, 2011; Masenyetse and Motelle, 2012; Musaba, Chilonda and Matchaya, 2013; Paul and Furahisha, 2017; Thamae, 2013). All these determinants have been backed by a strong theoretical and empirical review. Nonetheless there is inconsistency on empirical findings on the determinants of education and health expenditure, see the work of (Angko, 2013; Chaabouni and Abednnadher, 2014; Guisan and Exposito, 2010; Corsetti, Meier and Müller, 2012; Kotera and Okada, 2017; Loto, 2011; Paul and Furahisha, 2017; Thamae, 2013). This section on literature survey is divided into twofold, the first part discusses the empirical review that was conducted based on general government expenditure on health and, second part conclude with literature on government expenditure on education. Colombier (2012) assessed the drivers of public health expenditure with special attention on Baumol's cost disease theory. The author used the Gourieroux-Holly-Monfort (GHM) test and assessed the consistency of the panel by fixed effect ad random effect carried out by Hausman specification test. The 
results depict that income is a key factor of public health expenditure. This suggested that Baumol's cost disease exert positive significant impact on health expenditure. In particular, the findings reveal that a $1 \%$ increase in the excess of wage increase over productivity growth in health care will increase the growth rate of public health expenditure by almost $0.2 \%$. The author further suggested that Baumol's hypothesis is more applicable in public health sector. Bates and Santerre (2013) examined the determinants of public expenditure on health in 50 United States of America. The main focus was to determine whether the Baumol cost disease applies in America. The authors used fixed effect model and two stage least squared estimation to estimate the parameters. The results provided that if health care expenditure increase more rapidly when the states wage increases exceed productivity gains. In line with the above mention study, this study concluded that the United States health care sector supports the Baumol's cost disease.

Public expenditure on health, government effectiveness, education and the quality of life in Asia and Africa was assessed by Guisan and Exposito (2010). The results revealed that the only way to improve health spending is to raise spending on education. Moreover, the effects of education on health have both defensive measures to address malnutrition, water impurity and other negative circumstances. Grigoli and Kapsoli (2013) examined public expenditure on health with a special focus on its efficiency in emerging economies and developing economies. The authors used the Stochastic Frontier Model that control the socioeconomic determinants of public expenditure on health and provide economies specific estimates. The results indicated the at a current expenditure level, life expectancy can be push up by five years, when the economies are efficient in public expenditure on health. Novignon, Olakojo and Nonvignon (2012) examined the effect of both public and private expenditure on health and health status in Sub-Saharan Africa (SSA). Panel data from 1995 to 2010 for 44 Sub-Saharan Africa economies was applied. The authors used both fixed and random effect models to analysis the effect of health expenditure on health outcomes. The results revealed that health care expenditure has significantly and positive influence on health status by improving life expectancy at birth, reducing mortality and death rate.

Phi (2017) assessed the determinants of health expenditure in OECD economies with focus on economic growth, demographics, medical progress and health care systems. The author uses both fixed effect and random effect models to examine the key drives of health expenditure in these economies. The results revealed the economic growth is the key determinants to health expenditure in these economies while positive correlation between health expenditure and income was found to be significant. This suggest that health expenditure is responsive to income in the region, with elasticity value of 0.78 . Furthermore, the authors suggested that the government of this economies should provide more of health expenditure, since health care is responsive to income change. On education studies, Mussagy and Babatunde (2015) studies the relationship between public expenditure on education and economic growth in Mozambique using quarterly data from 1996 to 2012 . The researchers used Johansen Cointegration approach to study the long run relationship between the variables and the error correction was used to evaluate the short run adjustment dynamics. The results revealed that government expenditure on education in Mozambique is low and have an adverse effect on economic growth. The researchers further suggested that the government of Mozambique should increase government expenditure on education in order to accelerate economic growth in the economy. Johansen cointegration techniques was applied by Loto (2011) in studying government expenditure of Nigeria at a sectoral level for the period 1980 to 2008. In particular, five sectors of government which are security, health, education, transportation, and communication. In testing stationarity and cointegration amongst the variables the author applied Augmented Dickey Fuller (ADF) and Johansen cointegration techniques. The result revealed that education was negatively and insignificantly connected to gross domestic product.

The work by Nyamongo and Schoeman (2010) studied the effect of quality of governance and education expenditure in Africa countries. Their study paid attention to corruption, political stability or instability and democracy. The authors used both bivariate and multivariate estimation analysis to achieve the objectives set. Their results indicated that corruption has an adverse effect on education expenditure, where most corrupt developing economies devote a small share of government expenditure on education. Moreover, political instability has also a negative impact on education, and democracy will have no impact on education plans. Urhie, Ewetan and Okodua (2016) conducted a comparative study on national income, government spending on education and education attainment for 91 economies. The objectives of the study were to determine the relationship between education expenditure and national income. The study deployed the correlation analysis to determine how public expenditure on education differs with national income groups over time. The results revealed that there is positive association among government expenditure on education and national income at a global level over 
time. In conclusion, more generally several factors have been identified in this literature section above. Firstly; there is no existing empirical literature on government expenditure on health and education in SADC countries. Except for the work of Mussagy and Babatunde (2015) which whoever focused on education and economic growth in Mozambique exclusively than considering SADC economies as an economic unit. Finally, the literature survey shows that no attention was given to study the phenomena within panel FMOLS and DOLS techniques. The interest of such use of techniques is that in a case of pre-existence of cointegration among the system it is best to use this parameter estimates since they do not require post-estimation diagnostics. Therefore, this gap warrants an investigation in SADC economies.

\section{RESEARCH METHODOLOGY}

The purpose of the section is to outline the methods used to study the determinants of government expenditure on education and health.

\subsection{Model Description}

Equation (1) is the adopted and modified model of Yildirim and Sezgin (2002), which the study will apply to examine the determinants of government expenditure on health.

$H E_{i t}=\beta_{0}+\beta_{1} C O R_{i t}+\beta_{2} E D U_{i t}+\beta_{3} P O P_{i t}+\beta_{4} G D P_{t}+$ $\beta L I F E_{i t}+\varepsilon_{i t}$

Where, HE denotes health expenditure, COR represent corruption, EDU for education expenditure, $P O P$ for population growth rate, GDP denotes gross domestic product, and LIFE for life expectancy at birth.

On the education, this study assesses the determinants government expenditure on education by adapting and modifying the model of Busemeyer (2007). Thus, the following equation is used in this study.

$$
\begin{aligned}
& E D U_{i t}=\beta_{0}+\beta_{1} C O R_{i t}+\beta_{2} G D P_{i t}+\beta_{3} P O P_{i t}+\beta_{4} H E_{i t}+ \\
& \beta_{5} T E_{i t}+\varepsilon_{i t}
\end{aligned}
$$

Where, EDU represents education expenditure, COR for corruption, $P O P$ for population growth rate, $H E$ for health expenditure as percentage of GDP, GDP for gross domestic product, TE for tertiary enrolment and $\varepsilon$ for error term. The subscripts $i$ and $t$ indicates the cross section and times series respectively.

\subsection{Data Collection}

All the data is obtained from the African Development Indicators published by the World Bank. The data applied is the annul data covering the period from 1997 to 2017. The education expenditure collected from African Development Indicators and UNESCO data, it worth noting that it had missing values in all the sources, thus the education expenditure data was extrapolated to fill in the miss values. The unit of measure of all the variables are in percentages except of corruption which is an index.

\subsection{Estimation Methods}

The difficulty with time series data is that independent variables can appear to be significant than they actually are, if it has the same trend as the dependent variables. Thus, non-stationary variables to appear to be related even if they are not related. Therefore, the current study needs to test for stationarity conditions of variables in order to avoid spurious regression. The stationarity of the variables is examined using both the unit root tests developed by Levin, Lin and Chu (LLC) (2002) and Im, Pesaran and Shin (2003). The next step is to test for cointegration among those variables using Pedroni (1999) and Pedroni (2001). Pedroni proposed the following model in test for cointegration among the variables which is residual based:

$$
\begin{aligned}
& y_{i t}=\gamma_{i t}+k_{i t}+\lambda_{i} x_{i t}+\varepsilon_{i t} \\
& \varepsilon_{i t}=\phi_{i} \varepsilon_{i t-1}+\omega_{i t}
\end{aligned}
$$

Where for $i=1,2 \ldots, N$ for each unit in the panel, $t=1$, $2 \ldots, T$. Where $\gamma$ denote the fixed effect and $\lambda$ represent the slope coefficient permitted to change cross individuals' unit in equation 3 . In model $4, \phi$ is the autoregressive coefficient of the residual $\varepsilon$ it in equation 3. This study applies non-stationary estimation techniques, Fully-Modified OLS and Dynamic OLS models. Phillips and Hansen (1990) modified OLS to produce FM-OLS, to provide optimal estimates of cointegrating regression. The reason behind modifying OLS was to account for serial correlation effects and for the endogeneity in the regressors that results from the existence of cointegrating relationship between variables. The results from FM-OLS estimators are asymptotically unbiased and has fully effective mixture normal asymptotic permitting for standard Wald test, using asymptotic Chi-squares statistical inference. The panel Fully Modified OLS estimator for long run parameters can be defined geometrical as follows:

$$
\begin{aligned}
& \beta_{i} f \text { mols }=N^{-1} \sum_{i-1}^{N}\left\lfloor\sum_{i-1}^{T}\left(x_{i t}-\ddot{X}_{i t}\right)^{2}\right\rfloor\left[\sum _ { t - 1 } ^ { T } \left(x_{i t}-\right.\right. \\
& \left.\left.\ddot{X}_{i t}\right) \mu_{i t}^{*}-T_{Y_{i}}\right]-1
\end{aligned}
$$

Where:

$\mu_{i t}^{*}=\mu_{i t}-\frac{\underline{\mathrm{L}}_{2 l i}}{\mathrm{~L}_{22 i}} \Delta x_{i t} \tilde{\mathrm{Y}}_{i t} \equiv \Gamma_{2 l i}+\Omega_{2 l i}^{0}-\frac{\hat{\mathrm{L}}_{2 l i}}{\hat{\mathrm{L}}_{2 l i}} \quad\left(\dot{\Gamma}_{22 i}+\Omega_{22 i}^{0}\right)$ 
The former equation describes the transformed variables of $y_{i t}$ to attain endogeneity correction. The latter equation also defines the serial correlation term and $L_{i}$ is a lower triangular decomposition of $\Omega_{i}$ which is the covariance metrics and can be defined as follows:

$\Omega_{i}=\left[\begin{array}{ll}\Omega_{11} & \Omega_{12} \\ \Omega_{21} & \Omega_{22}\end{array}\right]$

Where $\Omega_{11}$, is the long-run scalar variance of the residual $\mu_{i t}$ and $\Omega_{22}$ is the $M \times M$ long-run covariance among. $\varepsilon_{i t}$ is $M \times 1$ vector that provides the long-run covariance among the residuals $\mu_{i t}$ and each of the $\varepsilon_{i t}$

The dynamic ordinary least squares were established by Saikkonen (1991) and Stock and Watson (1993) to estimate and test hypothesis about cointegrating vector to panel data. Panel dynamic ordinary least squares is wholly parametric and gives a calculation convenient. The panel dynamic ordinary least Squares estimator for long run parameters can be defined geometrical as follows:

$y_{i t}=\alpha_{i}+\beta i x_{i t}+\sum_{k=q}^{q} c_{i k} \Delta x_{i t+k}+\mu_{i t}$

Where $\alpha_{i}$ represent cross section specific effects and $c_{i k}$ is the coefficient of a lead or lags of first differenced exogenous variables. While $\mu_{i t}$ is the error term which is assumed to be integrated for order zero. The parameter estimates of DOLS can be defined as follows:

$\beta i D O L s_{i t}=N^{-1} \sum_{I-1}^{N}\left(\sum_{t-1}^{T} \mathrm{z}_{i t} \hat{\mathrm{Z}}_{i t}\right)\left(\begin{array}{ll}\sum_{t-1}^{T} & \mathrm{z}_{i t} y_{i t}^{*}\end{array}\right)^{-1}$

Where $\mathrm{z}_{i t}=\left(x_{i t}-\ddot{\mathrm{X}}_{i t} \Delta x_{i t-k} \ldots . . \Delta x_{i t+k}\right)$

\section{EMPIRICAL RESULTS}

The study assesses panel unit root for all the variables included in the model. The study deploys the LLC and Im, Pesaran and Shin for panel unit root. Table 1, shows Levin, Lin and Chu and Im, Pesaran and Shin panel unit root for SADC economies. The first column shows the order of integration, followed the variable interest. The second column is the unit root test Levin, Lin and Chu, which can be tested under Constant, Constant and Trend, and None. The third column reveal $\mathrm{Im}$, Pesaran, and shin panel unit root test, which can be test under Constant, Constant and Trend only. Levin, Lin, and Chu test reveal that corruption, population and GDP are stationary at level, whereas the other are stationary at first difference. Im, Pesaran and Shin test reveal that education, population, corruption and GDP are stationary at levels, whereas the others are stationary at first difference.

Table 1: Panel Unit Root Test Results

\begin{tabular}{|c|c|c|c|c|c|c|}
\hline \multirow[b]{2}{*}{ Order of integration } & \multirow[b]{2}{*}{ variable } & \multicolumn{3}{|c|}{ Levin, Lin and Chu (LLC) } & \multicolumn{2}{|c|}{ Im, Pesaran and Shin } \\
\hline & & constant & Trend \& constant & None & Constant & trend $\&$ constant \\
\hline Level & $E D U$ & $\begin{array}{c}0.119 \\
(1.087)\end{array}$ & $\begin{array}{c}0.154 \\
(-1.985)\end{array}$ & $\begin{array}{c}0.864 \\
(0.370)\end{array}$ & $\begin{array}{l}0.000^{* * *} \\
(-6.6320\end{array}$ & $\begin{array}{l}0.012^{* *} \\
(-6.672)\end{array}$ \\
\hline First difference & $D E D U$ & $\begin{array}{c}0.000^{\star * *} \\
(-20.949)\end{array}$ & $\begin{array}{c}0.000^{\star \star *} \\
(-18.221)\end{array}$ & $\begin{array}{c}0.000^{\star \star *} \\
(-23.848)\end{array}$ & $\begin{array}{l}0.000^{\star * \star} \\
(-19.753)\end{array}$ & $\begin{array}{c}0.000^{\star \star *} \\
(-17.581)\end{array}$ \\
\hline Level & $H E$ & $\begin{array}{c}0.218 \\
(-1.043)\end{array}$ & $\begin{array}{c}0.5931 \\
(-1.435)\end{array}$ & $\begin{array}{l}0.8592 \\
(1.097)\end{array}$ & $\begin{array}{c}0.181 \\
(-1.666)\end{array}$ & $\begin{array}{c}0.383 \\
(-1.225)\end{array}$ \\
\hline First difference & $D H E$ & $\begin{array}{c}0.000^{* * *} \\
(-13.656)\end{array}$ & $\begin{array}{c}0.000^{* * *} \\
(-12.238)\end{array}$ & $\begin{array}{c}0.000^{* * *} \\
(-16.160)\end{array}$ & $\begin{array}{l}0.000^{* * *} \\
(-11.919)\end{array}$ & $\begin{array}{l}0.000^{* * *} \\
(-9.619)\end{array}$ \\
\hline Level & $G D P$ & $\begin{array}{l}0.000^{* * *} \\
(-7.946)\end{array}$ & $\begin{array}{l}0.000^{* * *} \\
(-7.493)\end{array}$ & $\begin{array}{l}0.002^{* * *} \\
(-4.553)\end{array}$ & $\begin{array}{l}0.000^{* * *} \\
(-7.761)\end{array}$ & $\begin{array}{l}0.007^{* * *} \\
(-5.262)\end{array}$ \\
\hline Level & POP & $\begin{array}{l}0.000^{* * *} \\
(-4.845)\end{array}$ & $\begin{array}{c}0.000^{\star * *} \\
(5.345)\end{array}$ & $\begin{array}{c}0.053^{*} \\
(-6.564)\end{array}$ & $\begin{array}{l}0.000^{* * *} \\
(-10.676)\end{array}$ & $\begin{array}{c}0.000^{\star * *} \\
(-12.765)\end{array}$ \\
\hline Level & LIFE & $\begin{array}{c}0.996 \\
(0.496)\end{array}$ & $\begin{array}{c}0.657 \\
(-0.448)\end{array}$ & $\begin{array}{c}1.000 \\
(8.626)\end{array}$ & $\begin{array}{c}0.999 \\
(6.949)\end{array}$ & $\begin{array}{c}0.522 \\
(0.322)\end{array}$ \\
\hline First difference & DLIFE & $\begin{array}{l}0.014^{* * *} \\
(-7.167)\end{array}$ & $\begin{array}{c}0.925 \\
(8.505)\end{array}$ & $\begin{array}{l}0.000^{* * *} \\
(-11.398)\end{array}$ & $\begin{array}{c}0.000^{* * *} \\
(-11.735)\end{array}$ & $\begin{array}{l}0.000^{* * *} \\
(-7.537)\end{array}$ \\
\hline Level & $T E$ & $\begin{array}{c}0.996 \\
(2.697)\end{array}$ & $\begin{array}{c}0.313 \\
(-0.548)\end{array}$ & $\begin{array}{c}1.000 \\
(7.626)\end{array}$ & $\begin{array}{c}1.000 \\
(5.949)\end{array}$ & $\begin{array}{c}0.467 \\
(0.486)\end{array}$ \\
\hline First difference & DTE & $\begin{array}{l}0.018^{* *} \\
(-7.167)\end{array}$ & $\begin{array}{l}0.017^{* *} \\
(-8.505)\end{array}$ & $\begin{array}{l}0.000^{* * *} \\
(-11.398)\end{array}$ & $\begin{array}{l}0.000^{* * *} \\
(-11.735\end{array}$ & $\begin{array}{l}0.000^{* * *} \\
(-10.327)\end{array}$ \\
\hline Level & COR & $\begin{array}{l}0.000^{\star * *} \\
(-2.435)\end{array}$ & $\begin{array}{c}0.02^{*} \\
(-4.456)\end{array}$ & $\begin{array}{c}0.421 \\
(0.168)\end{array}$ & $\begin{array}{l}0.011^{* *} \\
(-5.787)\end{array}$ & $\begin{array}{c}0.056^{*} \\
(-3.987)\end{array}$ \\
\hline
\end{tabular}

Notes: $\left.\left({ }^{*}\right),\left({ }^{* *}\right),{ }^{* * *}\right)$ represent $10 \%, 5 \% 1 \%$ level of significant respectively. 
Table 2: Pedroni Panel Cointegration Test on Education and Health Expenditure

\begin{tabular}{|c|c|c|c|}
\hline & & Health expenditure & Education expenditure \\
\hline \multicolumn{2}{|c|}{ Methods } & (t-statistic) Probability value & (t-statistic) Probability value \\
\hline \multirow{4}{*}{$\begin{array}{l}\text { Within dimension/ panel } \\
\text { statistic }\end{array}$} & Panel v-statistics & $(-2.632), 0.995$ & $(-2.086), 0.981$ \\
\hline & Panel rho-statistics & $(1.234), 0.891$ & $(-0.171), 0.432$ \\
\hline & Panel PP-statistic & $(-11.007) 0.000^{* * *}$ & $(-23.785) 0.000^{* * *}$ \\
\hline & Panel ADF-statistics & $(-4.368) 0.000^{* * *}$ & $(-4.692) 0.000^{* * *}$ \\
\hline \multirow{3}{*}{$\begin{array}{c}\text { Between dimension / group } \\
\text { mean statistic }\end{array}$} & Group rho-statistics & (2.910) 0.998 & (0.905) 0.817 \\
\hline & Group PP-statistics & $(-15.777) 0.000^{* * *}$ & $(-35.392) 0.000^{* * *}$ \\
\hline & Group ADF-statistics & $(-3.839) 0.000^{\star * *}$ & $(-4.675) 0.000^{* * *}$ \\
\hline
\end{tabular}

Notes: $\left({ }^{\star}\right),\left({ }^{* \star}\right),\left({ }^{* \star *}\right)$ represent $10 \%, 5 \% 1 \%$ level of significant respectively.

Thus, this study will apply non-stationary models, since the variables are integrated for different orders.

Table 2 report the Pedroni cointegration test on health and education, which is divided into two groups, within dimension and Between Dimension statistics. The value on the brackets shows the estimation statistics. The null hypothesis of Pedroni cointegration test is that there is no cointegration between the variables. Therefore, if the probability values of the within and between dimension are below level of significant, we reject the null hypothesis and concluded that there is cointegration between the variables.

On health model, within test shows that PP-statistic and ADF statistic are both below any indicated significance level. Therefore, under this test we can reject the null hypothesis and conclude that there is cointegration between the variables. Panel rho statistics and panel V-statistics are both above level of significance indicated. This implies that under panel rho and panel v-statistics we failed to reject the null hypothesis and conclude that there is no cointegration between the variables. Therefore, we cannot conclude about cointegration relationship without considering the between dimension results. Since there is a stalemate between the four tests, two claiming no cointegration and the other two claiming cointegration between the variables.

The between dimension statistics reveals 0.891 p-value of group rho statistics, which is above $10 \%$ level of significant. However, the table shows 0.000 and 0.000 p-values of PP-statistics and ADF statistics which are below $1 \%$ level of significant respectively. Therefore, two out of three between dimension group statistics rejects the null hypothesis that there is no cointegration. Majority of between dimension statistics reveals that the variables are cointegrated. The aggregate results of Pedroni cointegration test contend that there is cointegration between health expenditure and their potential determinants.
On education model, within test shows that PP-statistic and ADF statistic are equally below $1 \%$ level of significant. Therefore, under this test we can reject the null hypothesis and conclude that there is cointegration between the variables. Panel V-statistics and Panel rho statistics are both above any level of significance. This indicates that under panel rho and panel v-statistics we failed to reject the null hypothesis and conclude that there is no cointegration between the variables. Therefore, we cannot conclude about cointegration relationship without considering the between dimension results. Since there is a draw between the four tests, two claiming no cointegration and the other two claiming cointegration between the variables

The between dimension statistics reveals 0.986 p-value of group rho statistics, which is above any significance level. However, the table shows 0.000 and $0.000 \mathrm{p}$-values of PP-statistics and ADF statistics which are below $1 \%$ level of significant respectively. Therefore, two out of three between dimension group statistics rejects the null hypothesis that there is no cointegration. Majority of between dimension statistics reveals that the variables are cointegrated. The aggregate results of Pedroni cointegration test contend that there is cointegration between education expenditure and its potential determinants.

Table 3 present the fully modified OLS and Dynamic OLS results with health expenditure as the dependent variable. The first column is the FMOLS results and last column is the DOLS results. FMOLS indicates that all the independent variables are significant except life expectancy variable. However, under DOLS only two variables that are significant which is education expenditure and corruption. In both FMOLS and DOLS shows that there is a positive insignificant relationship between health expenditure and life expectancy in SADC. FMOLS results show that there is positive and significant relationship between education expenditure and health expenditure in SADC. Therefore, $1 \%$ 
Table 3: Health Expenditure in SADC FMOLS and DOLS

\begin{tabular}{|c|c|c|c|c|}
\hline \multirow{2}{*}{ Variables } & \multicolumn{2}{|c|}{ Fully modified OLS } & \multicolumn{2}{c|}{ Dynamic OLS } \\
\cline { 2 - 5 } & Coefficient & Probability value & Coefficient & Probability value \\
\hline \hline LIFE & 0.075 & 0.197 & 0.007 & 0.9642 \\
\hline EDU & 0.264 & $0.000^{* * *}$ & 0.785 & $0.006^{* * *}$ \\
\hline GDP & -0.206 & $0.001^{* * *}$ & 0.015 & 0.192 \\
\hline POP & 0.080 & $0.000^{* * *}$ & 0.012 & $0.060^{*}$ \\
\hline COR & 0.743 & $0.000^{* * *}$ & -0.253 & 0.7958 \\
\hline
\end{tabular}

Notes: $\left({ }^{*}\right),\left({ }^{* *}\right),\left({ }^{* * *}\right)$ represent $10 \%, 5 \% 1 \%$ level of significant respectively.

increase in education expenditure will lead to $0.264 \%$ increase in health expenditure. Under DOLS the results show that there is positive significant relationship between health expenditure and education expenditure in SADC. One percent increase in education expenditure will results in $0.785 \%$ increase in health expenditure in SADC. Economic growth was found to be negative and significantly related to health expenditure in SADC under FMOLS. A $1 \%$ increase in economic growth will lead to $0.264 \%$ drop in health expenditure. DOLS revealed that positive and insignificant relationship between economic growth and health expenditure. A $1 \%$ increase in economic growth leading to $0.015 \%$ increase in health expenditure in SADC. Population has a positive significant relationship with health expenditure in SADC. One per cent increase in population will lead to $0.080 \%$ increase in health expenditure. The dynamic OLS model shows that there is positive and insignificant relationship between health expenditure and population, and 1\% increase in population growth will lead to $0.012 \%$ increase in health expenditure. Corruption has a positive and significant relationship with health expenditure according to FMOLS, and $1 \%$ increase in corruption will lead to $0.743 \%$ increase in health expenditure. On the other hand, DOLS shows that there is negative and significant relationship between health expenditure and corruption, and $1 \%$ increase in corruption will lead to $0.253 \%$ drop in health expenditure.
Table 4, under FMOLS it shows that education expenditure is positively and significantly related to higher education enrolments. A $1 \%$ increase in health expenditure will lead to $0.599 \%$ increase in education expenditure. Additionally, the dynamic OLS test also indicates that there is positive relationship between education and health expenditure in SADC. A $1 \%$ increase in health expenditure will lead to $0.925 \%$ increase in education expenditure. This results also indicates that education expenditure and health expenditure are complement rather than rivals. FMOLS reveals that gross domestic product has a positive and significant relationship with education expenditure in SADC. A $1 \%$ increase in gross domestic product will results in $0.0156 \%$ increase in education expenditure. In addition, the results show that population growth has a positive significant impact on education expenditure in SADC under FMOLS model. Thus $1 \%$ in population growth will lead into $0.038 \%$ increase in education expenditure in the region. Dynamic OLS also show that population growth has a positive impact on education expenditure, where $1 \%$ increase in population growth will lead to $0.056 \%$ increase in education expenditure in SADC.

Lastly, the results under FMOLS shows that corruption has a negative and significant relationship with education expenditure. Thus, $1 \%$ increase in corruption in SADC will lead to $0.337 \%$ increase in education expenditure. Whereas dynamic OLS model reveal a negative significant relationship between

Table 4: Education Expenditure in SADC FMOLS and DOLS

\begin{tabular}{|c|c|c|c|}
\hline \multirow{2}{*}{ Variable } & \multicolumn{2}{|c|}{ Fully modified OLS } & \multicolumn{2}{c|}{ Dynamic OLS } \\
\cline { 2 - 4 } & Coefficient & Probability value & Coefficient \\
\hline \hline TE & -0.646 & $0.000^{* * *}$ & -0.018 \\
\hline HE & 0.599 & $0.000^{* * *}$ & 0.925 \\
\hline GDP & 0.156 & $0.028^{* *}$ & -0.017 \\
\hline POP & 0.381 & $0.000^{* * *}$ & 0.056 \\
\hline COR & 0.337 & $0.000^{* * *}$ & $0.016^{* *}$ \\
\hline Adjusted R-squared & 0.565963 & & $0.000^{* * *}$ \\
\hline
\end{tabular}

Notes: $\left({ }^{*}\right),\left({ }^{* \star}\right),\left({ }^{* * \star}\right)$ represent $10 \%, 5 \% 1 \%$ level of significant respectively. 
education expenditure and corruption in SADC economies. A $1 \%$ increase in corruption will lead to 0.106 drop in education expenditure.

\section{CONCLUSION OF THE STUDY}

The aim of the study was to examine the effects of determinants of government expenditure on education and health in SADC countries. Thereafter, assess how these determinants affect the latter variables. This study employed panel data approach by applying data unit root tests such as Im, Pesaran and Shin (IPS) and Levin, Lin and Chu (LLC). In determining the long run relationship between the variables understudy the technique of Pedroni cointegration tests was applied. Furthermore, DOLS and FMOLS were applied to estimate the parameters for the variables. The study highlights that corruption and education expenditure are the significant determinants of health expenditure, whereas these results differ from those of Novignon, et al. (2012). Other results show that health expenditure, gross domestic product, population growth and corruption are the significant determinants of education expenditure in SADC countries. The findings are supported by both FMOLS and DOLS estimators which shows significant impact of health expenditure, corruption and higher education enrolments. Thus, there is a need for SADC governments to embark on implementing policies that increase education expenditure and corruption control policies to affect government expenditure. This can be achieved by allocating high budget on education expenditure and implementing independent agencies to combat corruption.

\section{REFERENCE}

African Development Bank Group. 2019. Southern Africa Economic outlook 2019; Macroeconomics Performance and prospects. https://www.afdb.org/fileadmin/uploads/afdb/Documents/Pub lications/2019AEO/REO_2019_-_Southern_africa.pdf. Retrieved. 10-October-2019

Angko, W. 2013. The determinants of healthcare expenditure in Ghana. Journal of Economics and Sustainable Development, 4 (15): 102-124.

Bates, L.J. \& Santerre, R.E. 2013. Does the US health care sector suffer from Baumol's cost disease? Evidence from the 50 states. Journal of health economics, 32 (2):386-391. https://doi.org/10.1016/j.jhealeco.2012.12.003

Busemeyer, M.R. 2007. Determinants of public education spending in 21 OECD democracies, 1980-2001. Journal of European Public Policy, 14 (4):582-610. https://doi.org/10.1080/13501760701314417

Chaabouni, S. \& Abednnadher, C. 2014. The determinants of health expenditures in Tunisia: An ARDL bounds testing approach. International Journal of Information Systems in the Service Sector (IJISSS), 6 (4):60-72. https://doi.org/10.4018/ijisss.2014100104

Colombier, C. 2012. Drivers of health care expenditure: Does Baumol's cost disease loom large? https://doi.org/10.2139/ssrn.2341054

Corsetti, G., Meier, A. \& Müller, G.J. 2012. What determines government spending multipliers? Economic Policy, 27 (72):521-565

https://doi.org/10.1111/j.1468-0327.2012.00295.x
Culyer, A.J. \& Newhouse, J.P. 2000. Handbook of health economics. Elsevier.

Grigoli, F. \& Kapsoli, J. 2013. Waste not, want not: the efficiency of health expenditure in emerging and developing economies. https://doi.org/10.5089/9781484364260.001

Devkota, S.P., Chaulagain, R. \& Bagale, S. 2016. Public expenditure in education sector of Nepal. The Online Journal of New Horizons in Education-April, 6 (2).

Dormont, B., Grignon, M. and Huber, H., 2006. Health expenditure growth: reassessing the threat of ageing. Health economics, 15(9), pp.947-963 https://doi.org/10.1002/hec.1165

Guisan, M.-C. \& Exposito, P. 2010. Health Expenditure, Education, Government Effectiveness and Quality of Life in Africa and Asia. Regional and Sectoral Economic Studies, 10 (1):115-126.

Gumede, W. 2010. Tackling Corruption Jacana., 02:15-23. https://doi.org/10.1088/2058-7058/23/02/25

Im, K.S., Pesaran, M.H. \& Shin, Y. 2003. Testing for unit roots in heterogeneous panels. Journal of econometrics, 115 (1):53-74.

https://doi.org/10.1016/S0304-4076(03)00092-7

Kotera, G. \& Okada, K. 2017. How does democratization affect the composition of government expenditure? Journal of Economic Behavior \& Organization. https://doi.org/10.1016/j.jebo.2017.03.004

Levin, A., Lin, C.-F. \& Chu, C.-S.J. 2002. Unit root tests in panel data: asymptotic and finite-sample properties. Journal of econometrics, 108 (1):1-24.

https://doi.org/10.1016/S0304-4076(01)00098-7

Loto, M. 2011. Impact of government sectoral expenditure on economic growth. Journal of Economics and International Finance, 3 (11):646-652

Masenyetse, R.F. and Motelle, S.I., 2012. Government revenue-expenditure nexus in Lesotho: the decline in SACU revenue. American Journal of Economics, 2(1), pp.8-14. https://doi.org/10.5923/j.economics.20120201.02

Musaba, E.C., Chilonda, P. and Matchaya, G., 2013. Impact of government sectoral expenditure on economic growth in Malawi, 1980-2007. Journal of Economics and Sustainable Development, 4(2), pp.71-78.

Mussagy, I.H. \& Babatunde, M.A. 2015. Government Spending on Education and Economic Growth in Mozambique: A Cointegration Approach. Revista Electrónica de Investigação e Desenvolvimento, (5).

Novignon, J., Olakojo, S.A. \& Nonvignon, J. 2012. The effects of public and private health care expenditure on health status in sub-Saharan Africa: new evidence from panel data analysis. Health economics review, 2 (1):22. https://doi.org/10.1186/2191-1991-2-22

Nyamongo, M. \& Schoeman, N.J. 2010. The quality of governance and education spending in Africa. Southern African Business Review, 14 (2).

Paul, F. \& Furahisha, G. 2017. Government expenditure and economic growth nexus: Wagner's law or Keynesian hypothesis for Tanzania? African Journal of Economic Review, 5 (1):32-47.

Pedroni, P. 1999. Critical values for cointegration tests in heterogeneous panels with multiple regressors. Oxford Bulletin of Economics and statistics, 61 (s 1):653-670. https://doi.org/10.1111/1468-0084.61.s1.14

Pedroni, P. 2001. Fully modified OLS for heterogeneous cointegrated panels. (In Nonstationary panels, panel cointegration, and dynamic panels. Emerald Group Publishing Limited. p. 93-130). https://doi.org/10.1016/S0731-9053(00)15004-2

Phi, G. 2017. Determinants of health expenditure in OECD Countries. Senior capstone project.

Phillips, P. C., and Hansen, B.E., 1990. Statistical inferences instrumental variable regression with I (1) processes. The review of economics studies, 57(1), PP. 99-125. https://doi.org/10.2307/2297545 
SADC. 1999. Protocol on Health in Southren Africa Development community. Paper presented at the SADC Health protocol. Retrieved 27 july 2017. from, www.sadc.int/ documents-publication/show/804

SADC. 2011 population review in SADC. Retrieved, http://www.hst. org.za/publications/NonHST\%20Publications/SADC_Region al_Assessment_2011-2012.pdf

SADC. 2017. Action Plan for SADC Industrialization Strategy and Roadmap. Paper presented at the ROADMAP. Retrieved 27 july 2017 https://www.google.com/search?rlz.

SADC. 2018 health review in SADC. Retrived, http://genderlinks.org. za/wp-content/uploads/2018/11/1-Final-signed-SADC-SRHR -Strategy-2019-2030.pdf

SADC. 2019a. https://www.sadc.int/themes/health/ Retrieved. 07-October-2019

SADC. 2019b. https://www.sadc.int/themes/health/communicablediseases/. Retrieved 07-October-2019

Saikkonen, P., 1991. Asymptotically efficient estimation of cointegration regressions. Econometrics theory, 7(1), 1-21. https://doi.org/10.1017/S0266466600004217

Stock, J.H. and Watson, M., 1993. Introduction to" business cycle, Indicators and forecasting" In Business cycle, indicators and forecasting" pp. 1-10. University of Chicago press. https://doi.org/10.7208/chicago/9780226774749.001.0001
Thamae, R.I. 2013. The growth of government spending in Lesotho. Economic Analysis and Policy, 43 (3):339-352. https://doi.org/10.1016/S0313-5926(13)50035-X

UN. 2015. The Millennium Development Goals Report 2015 UNITED. New York. Retrieved, 27/july/2018.From,/www.google.com/ search?q=The+Millennium+Development+Goals+Report+20 15+UNITED\&rlz=1C1GCEA enZA775ZA775\&oq=The+Mille nnium+Development+Goals+Report+2015+UNITED\&aqs $=c$ hrome..69i57j0.2696j0j8\&sourceid=chrome\&ie=UTF-8

Urhie, E., Ewetan, O.O. \& Okodua, H. 2016. National Income, Public Expenditure on Education and Educational Attainment: A Comparative Analysis. Covenant Journal of Business and Social Sciences, 6 (2).

Yildirim, J. \& Sezgin, S. 2002. Defence, education and health expenditures in Turkey, 1924-96. Journal of Peace Research, 39 (5):569-580. https://doi.org/10.1177/0022343302039005004

Yildirim, J. \& Sezgin, S. 2002. Defence, education and health expenditures in Turkey, 1924-96. Journal of Peace Research, 39 (5):569-580. https://doi.org/10.1177/0022343302039005004

World malaria report. 2019. Geneva: World Health Organisation; 2019. Licence CC BY-NC-SA.3.0 IGO. Retrieved date 2020 February 08.

DOI: https://doi.org/10.6000/1929-7092.2020.09.36

(c) 2020 Mhlari and Mosikari; Licensee Lifescience Global.

This is an open access article licensed under the terms of the Creative Commons Attribution Non-Commercial License (http://creativecommons.org/licenses/by-nc/3.0/) which permits unrestricted, non-commercial use, distribution and reproduction in any medium, provided the work is properly cited. 